\title{
CHEMICAL HETEROGENEITY OF INCONEL 625 LASER OVERLAY WITH AN INCREASED MOLYBDENUM CONTENT AND ITS EVALUATION USING THE POTENTIODYNAMIC CORROSION TEST
}

\author{
1Pavla KLUFOVÁ, ${ }^{2}$ Marek VOSTŘÁK, ${ }^{1}$ Antonín KŘíž \\ ${ }^{1}$ Department of Material Science and Technology, Faculty of Mechanical Engineering, University of West \\ Bohemia, Czech Republic,EU, klufovap@fst.zcu.cz,kriz@kmm.zcu.cz \\ ${ }^{2}$ New Technologies - Research Centre, University of West Bohemia, Czech Republic, EU, \\ https://doi.org/10.37904/metal.2019.721 \\ mvostrak@ntc.zcu.cz
}

\begin{abstract}
The paper focuses on a detailed analysis of chemical heterogeneity of Inconel 625 overlays with an increased molybdenum content deposited by laser cladding. Fifteen samples of laser overlays on S355J2 steel were prepared, each with an area of $90 \times 140 \mathrm{~mm}$. The thickness of the steel substrate was $50 \mathrm{~mm}$. During the laser cladding process, the temperature field on the face of the substrate was monitored by means of a thermal imaging camera. The surfaces of the Inconel 625 overlays were then machined to their final thickness. Corrosion potential, polarization resistance and corrosion rate in selected areas of laser clads were determined by the potentiodynamic corrosion test. These data were correlated with the temperature profiles during laser cladding and with microstructures of the overlays.
\end{abstract}

Keywords: Laser cladding, Inconel 625, heterogeneity, potentiodynamic corrosion test

\section{INTRODUCTION}

Laser cladding relies on the high-energy-density laser beam to melt the base material as well as the cladding material. The latter may be in the form of powder or wire. The cladding process produces a narrow region, in which the melted cladding material and base material become metallurgically bonded. Their solidification thus leads to strong metallurgical bonds which provide the deposit with good cohesion as well as adhesion to the base material. The goal of laser cladding is to create a weld clad with desired properties and chemical composition on the base material without extensive dilution (>10\%) between the two metals [1].

\section{HETEROGENEITY OF LASER OVERLAYS}

J. Liu et al characterized heterogeneity of laser overlays [2]. They assessed corrosion resistance of laser overlays with regard to their dilution and macrosegregation. According to [2], macrosegregation in laser overlays is caused by insufficient dilution in the weld pool. In laser welds, the weld pool solidifies in a manner similar to that of a dissimilar weld. As reported in [2], the key to reducing macrosegregation in laser overlays is to reduce the cladding speed. Larger heat input then leads to longer solidification times.

In laser cladding of intricate shapes, the previous bead always becomes partially melted during the next pass so that a continuous laser overlay can be formed. Both base material and the laser overlay experience a new thermal cycle with every pass. Therefore, it is the dynamics of laser cladding which affects the formation of non-equilibrium structures and chemical heterogeneity [1].

\section{EXPERIMENTS}

In this experimental programme, a total of 15 samples were prepared using laser cladding. The base material was S355J2 steel of $50 \mathrm{~mm}$ thickness which was ground on both sides. The chemical composition of the base material is given in Table 1 . 
Table 1 Chemical composition of S355J2 steel base material, element content in weight per cent [3]

\begin{tabular}{|c|c|c|c|c|c|}
\hline \multirow{2}{*}{ S355J2 steel, base material } & $\mathbf{C}$ & Mn & Si & P & S \\
\cline { 2 - 6 } & Max. 0.22 & Max. 1.6 & Max. 0.55 & Max. 0.025 & Max. 0.025 \\
\hline
\end{tabular}

Inconel 625 was chosen as the laser cladding material. This basic cladding powder mixture is made by Messer Eutectic Castolin under commercial name EuTroLoy 16625.04 (its chemical composition is given in Table 2). The Inconel 625 powder particles in the mixture were 50-150 $\mu \mathrm{m}$ in diameter.

Table 2 Chemical composition of EuTroLoy 16625.04 powder (Inconel 625), element content in weight per cent [4]

\begin{tabular}{|l|c|c|c|c|c|}
\hline \multirow{2}{*}{ EuTroLoy 16625.04 powder } & $\mathbf{C r}$ & Mo & Fe & Nb & C \\
\cline { 2 - 6 } & 21.00 & 9.00 & 3.00 & 3.00 & 0.05 \\
\hline
\end{tabular}

In an effort to improve the corrosion resistance of Inconel 625 overlays, various amounts of high-purity molybdenum powder were added to the EuTroLoy 16625.04 powder. Chemical composition of the molybdenum powder is listed in Table 3.

Table 3 Chemical composition of molybdenum powder, element content in weight per cent [5]

\begin{tabular}{|l|c|c|}
\hline \multirow{2}{*}{ Molybdenum powder } & Mo & Fe \\
\cline { 2 - 3 } & 99.7 & 0.3 \\
\hline
\end{tabular}

Laser cladding was carried out at New Technologies Research Centre (NTC) at the University of West Bohemia. Solid-state disc laser Trumpf TruDisk 8002 was used. Its wavelength was $\lambda=1030 \mathrm{~nm}$ and the spot size was $3.4 \mathrm{~mm}$. Weld cladding powder was supplied via powder feeder GTV PF 2/2 MH to coaxial-feeding cladding head Precitec YC52 with a four-beam nozzle. The assist and shielding gas was 99.99 \%-purity argon.

Laser cladding was performed using three different sets of process parameters. Table 4 summarizes designations of the samples, percentages molybdenum additions to the EuTroLoy 16625.04 powder mixture, and the cladding conditions.

Table 4 Designations of samples, sets of laser cladding parameters and amounts of the molybdenu powder added to EuTroLoy 16625.04

\begin{tabular}{|c|c|c|c|c|c|}
\hline \multirow{2}{*}{ Laser cladding parameters } & \multicolumn{5}{|c|}{ Powder mixtures EuTroLoy $16625.04+$ molybdenum [wt. \%] } \\
\cline { 2 - 7 } & $+\mathbf{0} \%$ Mo & $+2 \%$ Mo & $+4 \%$ Mo & $+6 \%$ Mo & + 8 \% Mo \\
\hline $\mathrm{P}=2000 \mathrm{~W} ; \mathrm{F} / \mathrm{S}=120 \mathrm{~g} / \mathrm{m} ; \mathrm{v}=30 \mathrm{~cm} / \mathrm{min}$ & $\mathrm{S} 1 \_0$ & $\mathrm{~S} 1 \_2$ & $\mathrm{~S} 1 \_4$ & $\mathrm{~S} 1 \_6$ & $\mathrm{~S} 1 \_8$ \\
\hline $\mathrm{P}=2500 \mathrm{~W} ; \mathrm{F} / \mathrm{S}=80 \mathrm{~g} / \mathrm{m} ; \mathrm{v}=30 \mathrm{~cm} / \mathrm{min}$ & $\mathrm{S} 2 \_0$ & $\mathrm{~S} 2 \_2$ & $\mathrm{~S} 2 \_4$ & $\mathrm{~S} 2 \_6$ & $\mathrm{~S} 2 \_8$ \\
\hline $\mathrm{P}=2750 \mathrm{~W} ; \mathrm{F} / \mathrm{S}=120 \mathrm{~g} / \mathrm{m} ; \mathrm{v}=30 \mathrm{~cm} / \mathrm{min}$ & $\mathrm{S} 3 \_0$ & $\mathrm{~S} 3 \_2$ & $\mathrm{~S} 3 \_4$ & $\mathrm{~S} 3 \_6$ & $\mathrm{~S} 3 \_8$ \\
\hline
\end{tabular}

Figure 1 shows a sketch of a laser-clad sample with dimensions of the base material and the overlay. Specimens for potentiodynamic corrosion testing were cut using water jet.

Figure 2 presents laser overlay specimen S3_2 and its macrosegregation region in a scanning electron micrograph. Differences between the macrosegregation structure and the structure of the $y$-matrix of the nickel overlay, as well as the interface between these regions can be seen. Figure 2 also shows the chemical composition of the macrosegregation region in weight per cent, as determined by EDX analysis. The dominant constituent of the macrosegregation region is iron which entered the laser overlay, together with carbon and other elements, as a consequence of the dilution between the S355J2 base material and the cladding powder. 


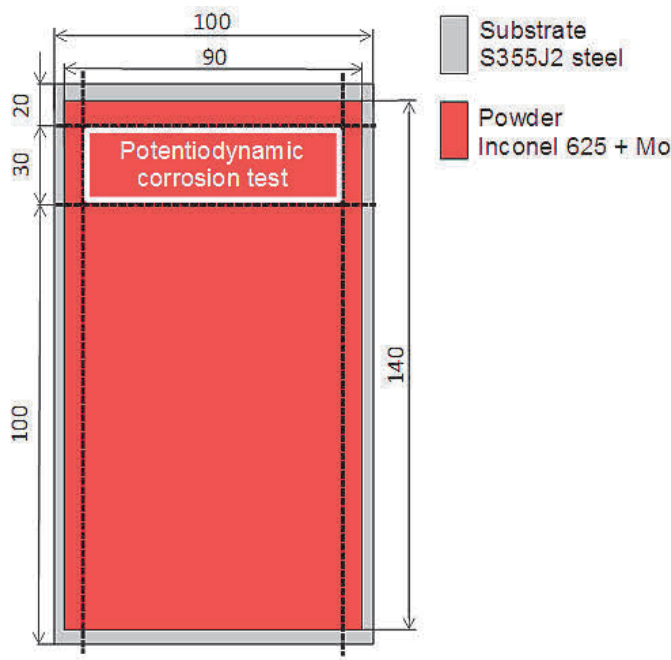

Figure 1 Sketch of experimental sample and location and dimensions of a specimen for potentiodynamic corrosion testing

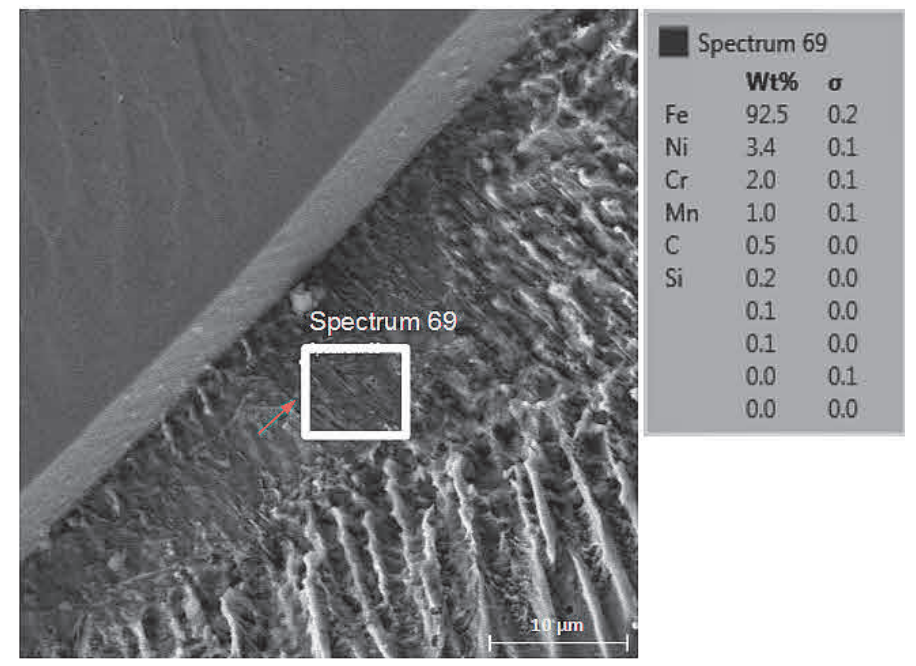

Figure 2 Specimen S3_2; macrosegregation region; the area of EDX chemical analysis is indicated; the inset shows the measured composition in wt. \%

\section{POTENTIODYNAMIC CORROSION TEST}

Corrosion resistance of the composite laser clads was assessed using potentiodynamic corrosion testing with the aid of BioLogic SP-150 potentiostat. EcLab 10.44 software was employed for data processing and evaluation. First, the time dependence was measured of the steady-state corrosion potential between WE WORKING ELECTRODE and RE - REFERENCE ELECTRODE. The time for stabilization of free corrosion potential was identical in all measurements $t_{R}=30 \mathrm{~min}$. The, linear polarization was used for finding the dependence of corrosion current (converted to current density) on the mixed corrosion potential of the sample within the range from $E_{i}$ to $E_{L}\left(\mathrm{E}_{\mathrm{i}}=\mathrm{E}_{\mathrm{corr}}-0.025[\mathrm{~V}] ; \mathrm{E}_{\mathrm{i}}=\mathrm{E}_{\mathrm{corr}}+0.025[\mathrm{~V}]\right)$ with respect to the reference electrode $(R E)$. The Tafel lines obtained were extrapolated using software EcLab 10.44 and the polarisation resistance $R_{p}[\mathrm{mV}]$ and corrosion rate $v_{\text {corr }}[\mu \mathrm{m} / \mathrm{year}]$ were determined [1]. The reference electrode (" $R E$ ") was a calomel electrode and the counterelectrode ("CE") was a $0.3 \mathrm{~mm}$ diameter platinum wire, which supplied electric current to the corrosion cell to induce voltage changes between the specimen and the calomel electrode. The electrolyte was a neutral $3.5 \% \mathrm{NaCl}$ solution in demineralized water at $\mathrm{pH} 7$.

The conditions of potentiodynamic corrosion testing are summarized in Table 5.

Table 5 Potentiodynamic corrosion test - measurement conditions

\begin{tabular}{|c|c|}
\hline Potentiodynamic corrosion test conditions & Quantitative values \\
\hline Time for stabilization of free corrosion potential tR & $30 \mathrm{~min}$ \\
\hline Corrosion potential measurement range (E Range) & $-2 ; 2 \mathrm{~V}$ \\
\hline Ewe working electrode potential recording vs. time (de/dt) & $0.166 \mathrm{mV} \cdot \mathrm{s}^{-1}$ \\
\hline Linear polarisation within the range $(\Delta \mathrm{E})$ & $\pm 0.025 \mathrm{~V}$ \\
\hline Specimen area $(\mathrm{S})$ & $177 \mathrm{~mm}^{2}$ \\
\hline Density of Inconel 625 & $8.4 \mathrm{~g} \cdot \mathrm{cm}^{3}$ \\
\hline Equivalent weight of Inconel 625 & $25,573 \mathrm{~g} \cdot \mathrm{eq}^{-1}$ \\
\hline
\end{tabular}

Locations of specimens used for corrosion testing of the laser overlays are shown in Figure 1. Prior to measurement, the surfaces of the laser overlays were activated by light manual sanding. The surface for 
placing the corrosion cell was cleaned thoroughly and blown dry. The specimen and the corrosion cell were then clamped in a fixture, the cell was filled with electrolyte and three electrodes of the measuring system were connected to a potentiostat.

Three measurements were performed on each laser-clad specimen. Since there were dramatic differences between the measurement readings, no arithmetic mean was calculated as the final result. Instead, individual measurements were interpreted separately with respect to heterogeneity of the particular laser overlay.

Included merely for illustration, Table 6 lists arithmetic means and standard deviations for the measured corrosion rates in laser overlays S1_0 through S1_8. The laser cladding parameters for these specimens were as follows: $P=2000 \mathrm{~W} ; \mathrm{F} / \mathrm{S}=120 \mathrm{~g} / \mathrm{m} ; \mathrm{v}=30 \mathrm{~cm} / \mathrm{min}$. The standard deviations ranged from $67 \%$ (specimen S1_0) to $99 \%$ (specimen S1_8) with respect to the arithmetic mean of corrosion rate. The author declines the possibility of any of the potentiodynamic measurements being invalid. As a proof, Figure 3 shows the polarisation curves for three measurements on specimen S1_8. The extrapolated polarisation curves exhibit the expected local minima in corrosion potential. In measurements 1 (blue curve) and 3 (green curve) both parts of the curve for electrode potential vs. current, i.e. anodic and cathodic reactions, were smooth and exponential. In measurement 2 which is shown in red in Figure 3, the Ewe-I dependence showed minor fluctuations, particularly in the cathodic reaction part. The occurrence of these peaks may be attributed to local chemical heterogeneities in the laser overlay. It is likely that the area of the corrosion cell on the surface of the laser overlay included a region, in which there were some other phases in the nickel matrix (e.g. iron-based and Laves-type phases, high-molybdenum precipitates and others) which led to non-uniform corrosion (pitting).

Table 6 Corrosion rates in specimens S1_0, S1_2, S1_4, S1_6, S1_8 determined by potentiodynamic corrosion testing, and standard deviations

\begin{tabular}{|c|c|}
\hline Specimen & Corrosion rate $\mathbf{v}$ corr $[\mu \mathrm{m} / \mathrm{year}]$; arithmetic mean and standard deviation \\
\hline S1_0 & $0.060 \pm 0.040$ \\
\hline S1_2 & $0.080 \pm 0.060$ \\
\hline S1_3 & $0.068 \pm 0.047$ \\
\hline S1_4 & $1.249 \pm 0.800$ \\
\hline S1_5 & $2.695 \pm 2.669$ \\
\hline
\end{tabular}

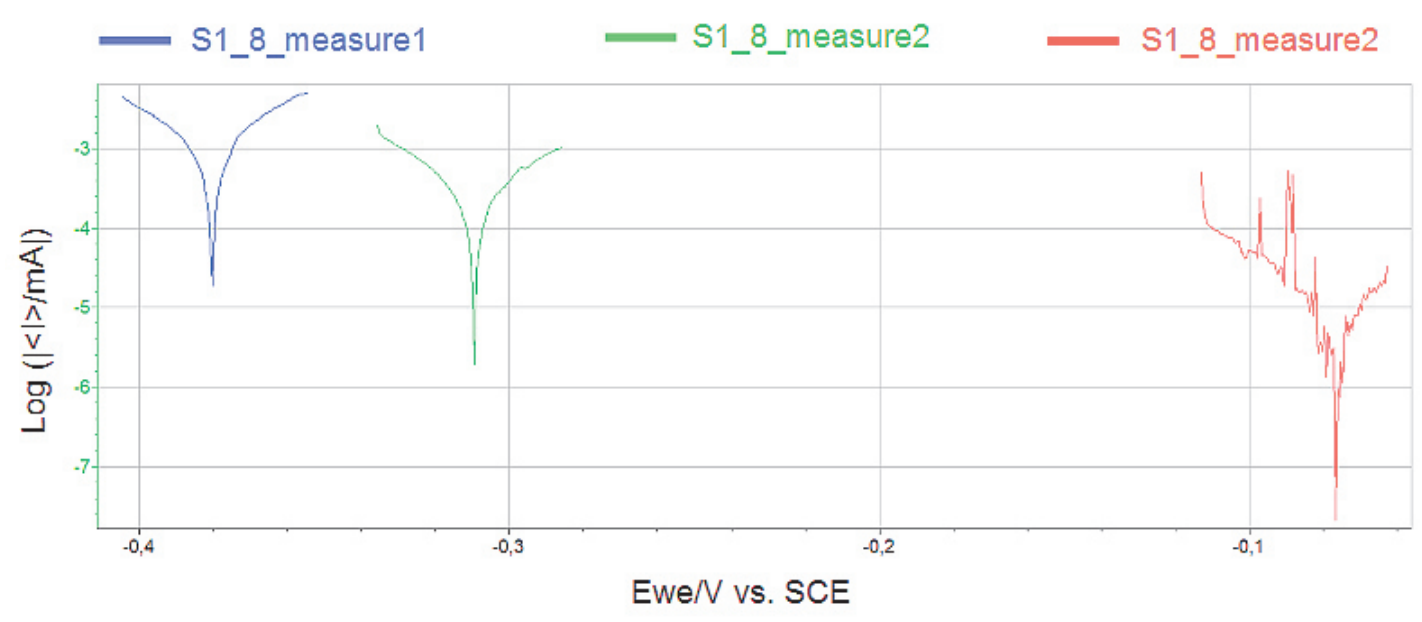

Figure 3 Specimen S1_8; potentiodynamic curves Ewe vs. log I for three measurements; blue curve - measurement 1; red curve - measurement 2, green curve - measurement 3 
In specimens S1_0 through S1_8, the stable corrosion potential between the working and reference electrodes $E_{c o r r}$ ranged from $-379 \mathrm{mV}$ to $+97 \mathrm{mV}$. The potential is a measure of the oxidation ability of the corrosion environment [6]. Although the interval of the measured corrosion potentials appears broad, it is in fact mere hundreds of millivolts, which is negligible with respect to linear polarisation, potentiodynamic curves, polarisation resistance $R_{p}$, and corrosion rate $v_{\text {corr }}$. The highest corrosion rate was $6.357 \mu \mathrm{m} / \mathrm{year}$ in specimen S1_8. In nickel alloys, corrosion rates $v_{\text {corr }}<5 \mu \mathrm{m} /$ year are generally accepted as negligible. The above condition was met in 14 out of the 15 measurements on specimens with laser overlays deposited at $\mathrm{P}=2000 \mathrm{~W} ; \mathrm{F} / \mathrm{S}=120 \mathrm{~g} / \mathrm{m}$ and $\mathrm{v}=30 \mathrm{~cm} / \mathrm{min}$. Nevertheless, Figure 4 shows an exponentially increasing dependence of corrosion rate on the amount of molybdenum addition to the laser cladding powder EuTroLoy 16625.04 (Inconel 625).

An opposite trend in the dependence of corrosion rate on the amount of molybdenum addition to the laser cladding powder EuTroLoy 16625.04 (Inconel 625) was found in overlays S2_0 through S2_8, which were made at $P=2500 \mathrm{~W} ; \mathrm{F} / \mathrm{S}=80 \mathrm{~g} / \mathrm{m} ; \mathrm{v}=30 \mathrm{~cm} / \mathrm{min}$. Here, corrosion rate decreased with increasing molybdenum content in the laser overlay.

The last series of laser-clad samples was prepared at $P=2750 \mathrm{~W} ; F / S=120 \mathrm{~g} / \mathrm{m}$ and v $=30 \mathrm{~cm} / \mathrm{min}$. Potentiodynamic testing of specimens S3_0 through S3_8 revealed an exponential increase of corrosion rate with increasing amount of molybdenum addition to the laser cladding powder EuTroLoy 16625.04 (Inconel 625).

Figure 4 compares corrosion rates $v_{\text {corr }}[\mu \mathrm{m} / \mathrm{year}]$ in laser overlays, as determined by the linear polarisation method in potentiodynamic corrosion tests.

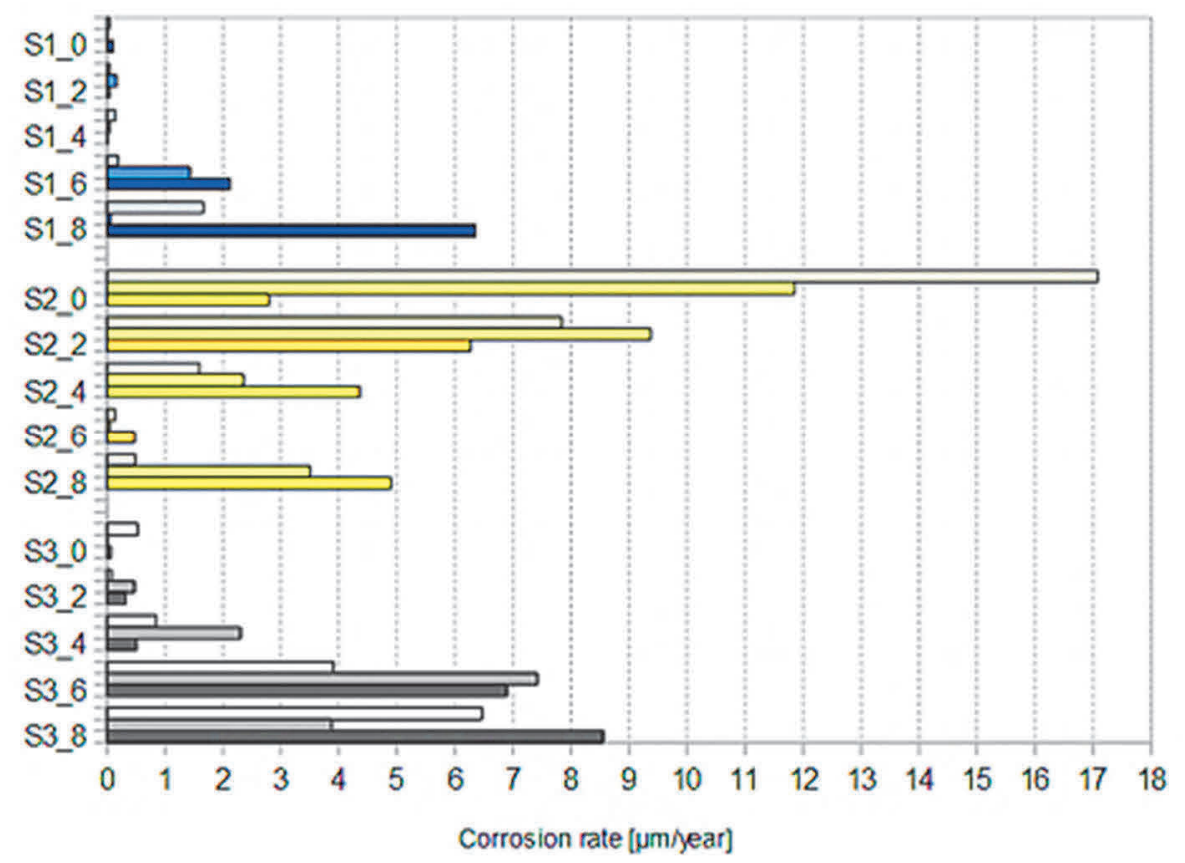

Figure 4 Potentiodynamic corrosion test; corrosion rate plots, $v_{c o r r}[\mu \mathrm{m} / \mathrm{year}]$, for laser overlays

The values depend on the laser cladding conditions and on the amount of molybdenum added to the laser cladding powder EuTroLoy 16625.04 (Inconel 625). In addition, the corrosion rates differ in each of the three measurements on the same specimen. In nickel alloys, corrosion rates $v_{\text {corr }}<5 \mu \mathrm{m} /$ year are generally accepted as negligible. This condition was fully met in specimens S1_0; S1_2; S1_4; S1_6; S2_4; S2_6; S2_8; S3_0; S3_2 and S3_4. In the other laser overlay specimens S1_8; S2_0; S2_2; S3_6 and S3_8, this limit was exceeded by at least one corrosion rate calculated from the potentiodynamic measurement data. 


\section{CONCLUSION}

In this experimental programme, fifteen samples of Inconel 625 nickel alloy overlays were made by laser cladding. The laser cladding powder was EuTroLoy 16625.04, which was mixed with different amounts of highpurity molybdenum prior to cladding.

The laser overlays were confirmed to be heterogeneous by both metallographic observation in a scanning electron microscope, where appreciable macrosegregation regions were found in the overlays, and by potentiodynamic corrosion testing. Thanks to the compact area of the corrosion cell $\left(1.77 \mathrm{~cm}^{2}\right)$ the potentiodynamic corrosion test can capture minute chemical and structural heterogeneities in the laser overlays. They are manifested by measurable deviations in electrochemical reactions. In addition, heterogeneity of the laser-clad specimens was confirmed by variations in the dependence of the corrosion rate on molybdenum content in laser cladding powder EuTroLoy 16625.04 (Inconel 625).

\section{ACKNOWLEDGEMENTS}

The above investigation was funded by the Ministry of Education under the project LQ1603 entitled "Výzkum pro SUSEN". The work was carried out in a large infrastructure designated as "Udržitelná energetika (SUSEN)" which had been built under project CZ.1.05/2.1.00/03.0108.

\section{REFERENCES}

[1] KLUFOVÁ, Pavla. Odolnost proti degradaci laserem navařených austenitických vrstev. Disertační práce. Západočeská univerzita v Plzni. Plzeň 2018

[2] LIU, Jian, LI, Jia, CHENG, Xu, WANG, Huaming. Effect of dilution and macrosegregation on corrosion resistace of laser clad AerMet100 steel coating on 300M steel substrate. In Surface \& Coatings. Vol. 325. 2017. p. 352-359. ISSN 0257-8972

[3] BOHDAN BOLZANO, s.r.o. Nelegované konstrukční oceli. S355J2 [viewed 2019-05-02]. Avaiable from https://www.bolzano.czl

[4] CASTOLIN EUTECTIC, materiálový list dodavatele přídavného prášku EuTroLoy 16625.04

[5] BIBUS METALS, s.r.o. Podklady společnosti - niklové slitiny a jejich vlastnosti. [viewed 2018-02-04] Avaiable from (http://new.bibus.cz/pdf/Special Metals/Nikl/Niklove slitiny.pdf)

[6] NOVÁK, Pavel. Koroze kovů. Ústav kovových materiálů a korozního inženýrství. VŠCHT v Praze. [viewed 2018-01-30]. Avaiable from (https://ukmki.vscht.cz/files) 